\title{
Corporate Governance, Voluntary Disclosure, And Firm Information Environment
}

Sabri Boubaker, Ph.D., Champagne School of Management (Groupe ESC Troyes), France \& IRG, Université Paris Est, France Amal Hamrouni, Ph.D., La Rochelle Business School and University of Perpignan via Domitia, France

Qi-Bin Liang, Ph.D., University of Perpignan via Domitia, France

\begin{abstract}
This paper examines the relative performance of several corporate governance factors, specifically the characteristics of boards of directors, managerial ownership, and voluntary disclosure, in improving firm information environments. The paper uses a new empirical approach based on a B-convex method on a sample of 70 non-financial French listed firms belonging to the SBF120 index. Our findings show that $68.57 \%$ of our sample firms are located on the efficiency frontier. Corporate governance practices appear to serve as effective monitoring for the top executives of these firms, which reduces information asymmetry between insiders and outsiders, thereby improving the information environment. The empirical analysis also generates evidence that $31.42 \%$ of our sample firms lie outside the efficiency frontier. Corporate governance practices in many firms appear insufficient to improve firm information environments. These findings suggest the need for many SBF120 firms to improve their corporate governance practices.
\end{abstract}

Keywords: Corporate Governance; Ownership Structure, Voluntary Disclosure, B-Convex Method

\section{INTRODUCTION}

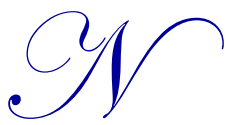

ot all investors in financial markets have access to the same information about firm quality, leading to an adverse selection problem since informed investors use their information advantage in their trading (Akerlof, 1970). This problem is likely to deepen capital market failures since it increases the number of transactions initiated by informed investors, which in turn increases transactions costs (e.g., O'Hara, 1995), widens dispersion in analyst forecasts (e.g., Zhang, 2006), and increases the cost of firm capital (e.g., Botosan, 1997).

Better corporate governance practices may mitigate the adverse selection problem and reduce information asymmetry (e.g., Chung et al., 2010). Agency theory provides a conceptual framework in which to study the relation between governance mechanisms and information asymmetry (Jensen and Meckling, 1976). Agency theory holds that the role of internal governance mechanisms and practices is important to ensuring that managers act in the best interests of shareholders, making decisions that maximize firm value and that guarantee a transparent environment to outsiders.

Fama and Jensen (1983) hold that the board of directors is the most important internal governance mechanism. The effectiveness of boards of directors depends, to a large extent, on their size and composition. Jensen (1993) argues that small boards are more effective, since information sharing and decision making processes are easier in these structures. However, Anderson et al. (2004), among others, argue that large boards ensure greater monitoring of the financial accounting process and improve firm transparency. Cai et al. (2006), for instance, provide evidence that the adverse selection problem is less important in U.K. firms with large boards. Using a 
sample of Canadian firms, Attig (2007) finds that firms with dispersed ownership and large boards exhibit lower information asymmetry (i.e., low price spreads).

Fama and Jensen (1983) argue that the effectiveness of a board depends on its independence. Independent directors improve the monitoring role of boards, since they ensure protection of the firm's overall interests against managers' potential opportunistic behavior. According to Dahya et al. (2008), independent directors are important in ensuring shareholders that the board properly fulfills its responsibility; their presence often constrains controlling shareholders from diverting corporate resources for private benefit. Independent directors also are less prone to undertaking self-serving behaviors at the expense of minority shareholders. Controlling shareholders are, thus, less inclined to withhold information from the financial markets. Therefore, the presence of independent directors is likely to improve the firm information environment and reduce information asymmetry between insiders and outsiders. Empirical evidence, such as that of Chen and Jaggi (2000) in Hong Kong and Kanagaretnam et al. (2007) in the US, is consistent with this prediction. Other empirical studies, such as Cheng and Courtenay (2006), Patelli and Prencipe (2007), and Barros et al. (2013), show that the presence of independent directors encourages firms to disclose further information to outsiders, which improves transparency and reduces information asymmetry. More recently, Botti et al. (2014) document inefficiency in the composition, structure, and functioning of French boards of directors. Using a sample of CAC40 firms, these authors empirically demonstrate that inefficient monitoring and oversight of top executives by boards leads to lower levels of internet financial reporting quality, which is likely to affect the information environment of these firms.

In addition to examining the board of directors, agency theory (Jensen and Meckling, 1976) presents managerial ownership as a governance mechanism that solves possible agency conflicts between managers and shareholders and that reduces potential agency costs. Managerial ownership is likely to reduce managers' discretionary behavior and to improve firm transparency, implying an improved firm information environment. There is limited empirical evidence on how managerial ownership affects the information environment. For instance, Attig et al. (2006) present evidence that firms with greater deviation between ownership and control exhibit higher information asymmetry. Unlike the entrenchment hypothesis, the incentive alignment hypothesis argues that managerial ownership can induce managers to adopt a self-serving attitude, to the detriment of other shareholders. Cheng and Warfield (2005), among others, empirically support the entrenchment hypothesis and demonstrate that equity incentives promote earnings management. These authors document that managers with high equity incentives are more likely to sell shares in the future, and this motivates earnings management to increase the value of the shares to be sold. Baik et al. (2010), however, demonstrate a negative relation between managerial ownership on the one hand, and analyst coverage and the likelihood of issuing earnings forecasts, on the other hand. These empirical findings are consistent with the hypothesis that managerial ownership leads to a more opaque information environment. According to signaling theory (Spence, 1973), good corporate disclosure policy is a means to mitigate adverse selection problems and improve the firm information environment. Grossman (1981) uses signaling theory to explain how firm financial disclosures are useful to reducing information asymmetry.

Theoretical studies predict that high-quality disclosures mitigate information asymmetry, attract more uninformed investors, and reduce the incentive of informed investors to search for private information (e.g., Diamond, 1985; Diamond and Verrecchia, 1991). Empirical research consistently shows that the quality of corporate disclosure, measured by the quality of earnings, negatively affects uncertainty and information asymmetry (Ascioglu et al., 2012). Similarly, Heflin et al. (2005) and Brown and Hillegeist (2007) use voluntary disclosure scores and show that the extent of corporate voluntary disclosure reduces information asymmetry. Brown and Hillegeist (2007) find that the quality of annual reports reduces information asymmetry, proxied by the probability of informed trading.

In the spirit of existing studies, we focus on annual reports as the main vehicle for communication of both mandatory and voluntary information between the firm and its stakeholders (e.g., Neu et al., 1998). Annual reports represent a key summary of firm performance indicators (e.g., Lang and Lundholm, 1996), and the level of information included is the best evidence of the level of firm disclosure (Zarb, 2007). Many studies examining disclosure policies in annual reports (e.g., Lang and Lundholm, 1993) demonstrate a positive relation between disclosure level and other forms of disclosure. 
The present study extends the literature and sheds additional light on the role of corporate governance practices (board characteristics, managerial ownership, and voluntary disclosure) on firm information environment. The empirical analysis uses the B-convex method on a sample of 70 French listed firms belonging to the SBF120 index in 2007. The empirical findings show that $68.57 \%$ of our sample firms are efficient. Corporate governance mechanisms seem to effectively monitor the top executives of these firms, which improves their information-related decisions and reduces information asymmetry between insiders and outsiders. A large proportion of our sample firms $(31.42 \%)$ lies below the efficiency frontier, with efficiency scores different from 1 . The corporate governance practices in these firms seem to be inefficient in improving the information environment.

This paper proceeds as follows. Section 2 presents our methodological approach. Section 3 outlines the sample, describes the data, and defines the inputs and outputs used in the B-convex method. Section 4 reports and discusses the main empirical findings. Finally, Section 5 sets forth our conclusions.

\section{METHODOLOGY: B-CONVEX METHOD}

Using a non-parametric approach, the Data Envelopment Analysis (DEA) method estimates the production frontiers distinguishing the efficient production units of those that are less. It is a tool with a growing interest in the field of operations research. Inasmuch as most of the social organization can be assimilated as a Decision Making Units transforming a set input to a set of output, therefore the scope of the DEA method is highly large. The Bconvex analysis is an innovate method in DEA introduced by Briec and Liang (2011). The advantage of this method is that it relaxes the assumption of convexity in the consideration of the production set. Now we will briefly present the definitions and results used in this paper, for more technical details readers can refer to Briec and Liang (2011).

Denote $I R_{+}^{d}$ be the non-negative Euclidean $d$-orthant; for $z, w \quad I R_{+}^{d} z \leq \boldsymbol{w}$ means that $z_{i} \leq w_{i} \forall_{i} \in\{1, \ldots, d\}$. Let $m, n \in I N$ be two positive natural numbers such that $d=m+n$. A production technology function transforms inputs $x=\left(x_{1}, \ldots, x_{m}\right)$ into outputs $y=\left(y_{1}, \ldots, y_{n}\right)$. The production set is the set $T \subset I R_{+}^{m+n}$ of all inputs-outputs vectors that are feasible. It is defined as follows:

$T=\left\{z=(x, y) \in I R_{+}^{m+n}: x\right.$ can produce $\left.y\right\}$

Let us consider $z^{1}, z^{2}, \ldots, z^{l} \in I R^{d}$, we denote

$$
\begin{aligned}
& x_{k=1}^{l}=\left(\max \left\{z_{1}^{1}, \ldots, z_{1}^{l}\right\}, \ldots, \max \left\{z_{d}^{1}, \ldots, z_{d}^{l}\right\}\right) \\
& T_{\max }=\left\{z=(x, y) \in I R_{+}^{d}: x \geq \underset{k=1}{1} \rho_{k} x^{k}, y \leq \underset{k=1}{1} \rho_{k} y^{k}, \max _{k=1 . . . l} \rho_{k}=1, \rho \geq 0\right\}
\end{aligned}
$$

is called a B-Convex estimation of the production technology. It assumes that a company can produce a greater quantity of outputs when she can use a greater quantity of inputs. When the maximum of two input bundles are feasible, then the maximum they produce is also feasible. The figure 1 illustrates the frontier of B-Convex production technology. 


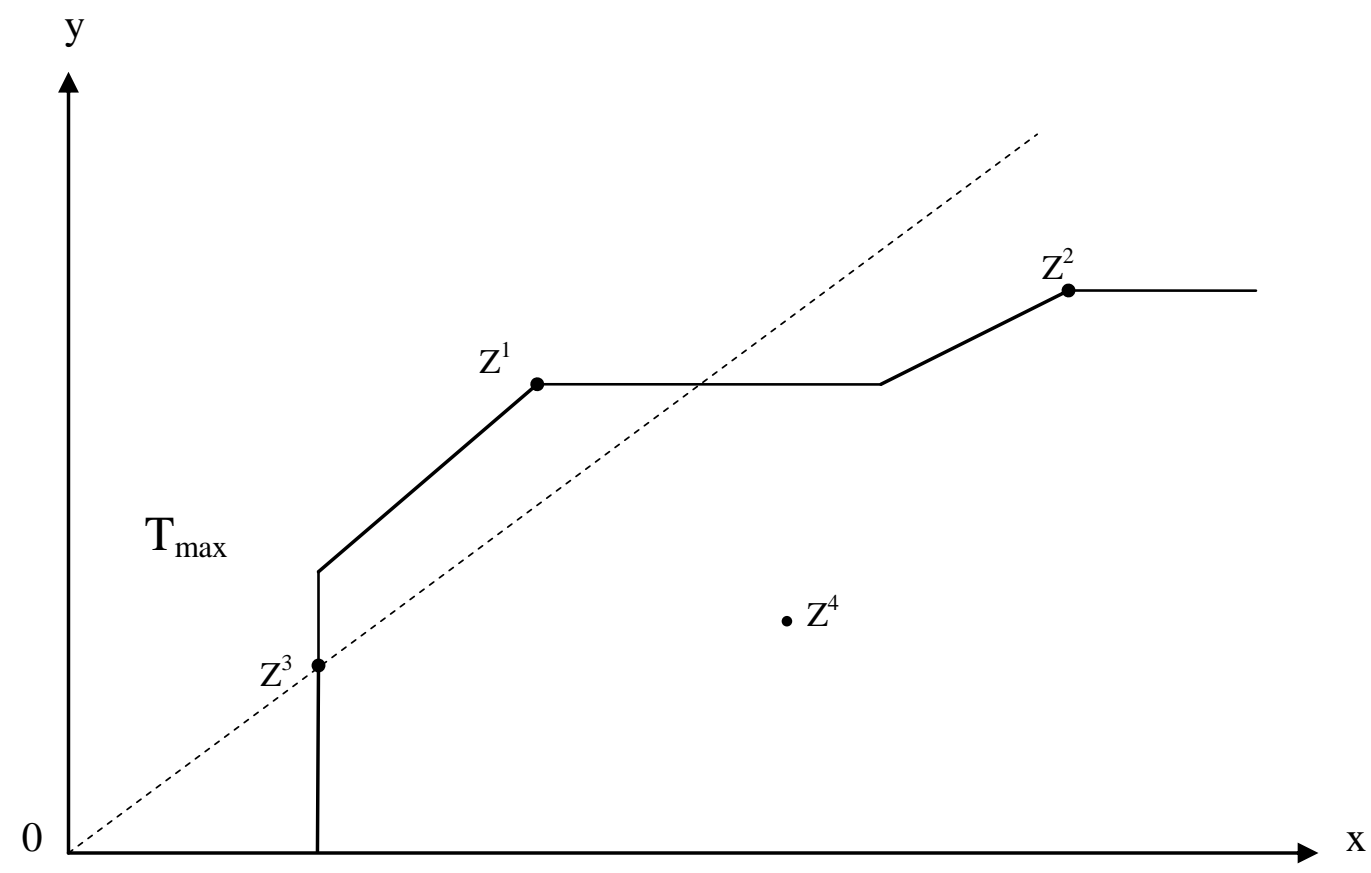

Figure 1. B-Convex Production Technology

B-Convexity includes, as a special case, a situation where inputs are assumed to be freely disposable. The B-Convexity approach implies, under this assumption, that the production set has an output cubic structure. In other words, an assumption of output complementarity is implicitly made on the technology. We employ the Farrell measure over the B-convex non-parametric technologies developed by Briec and Liang (2011). ${ }^{1}$

\section{DATA AND VARIABLE CONSTRUCTION}

\subsection{Sample Selection And Data Sources}

Our starting point is all French listed firms belonging to the SBF120 in 2007. We exclude financial firms (SIC codes between 6000 and 6999), because they are subject to specific disclosure requirements, and firms with missing data. Our final sample consists of 70 firms. We focus on the SFB120 firms because they are more likely to disclose detailed information in their annual reports and to adopt good governance practices. During the 2000s, French firms that won annual report awards were among the SBF120 firms. Corporate governance data are handcollected from firm annual reports available on the AMF website. ${ }^{2}$ Financial data are retrieved from the Worldscope Database. Stock price returns are from the Datastream database.

\subsection{Outputs}

This research uses a B-convex approach to examine the association between corporate governance, voluntary disclosure, and firm information environment for a sample of SBF120 firms. We consider three outputs that proxy for the quality of the firm information environment. First, we examine annual average effective bid-ask spreads (Spread), which is calculated as the yearly average of daily effective bid-ask spreads. Consistent with Lin et al. (1995) and Heflin et al. (2005), we measure the daily effective spread as twice the absolute value of the difference between a transaction price and the midpoint of the bid and ask prices. It is computed using the following formula:

\footnotetext{
${ }^{1}$ Mathemtica is used to program the algorithm that calculates the efficiency scores.

${ }^{2}$ AMF (Autorité des Marchés Financiers) is the French equivalent of the U.S Securities and Exchange Commission (SEC).
} 


$$
2\left|P_{t}-\left(\frac{A s k_{t}+B i d_{t}}{2}\right)\right|,
$$

where $A s k_{t}\left(B i d_{t}\right)$ is the best ask (bid) price on day $t$.

To assess annual average spread, we divide the sum of daily effective spreads by the total number of trading days during the quotation year.

Second, we examine analyst forecasts error (AnaError), which is measured as the absolute value of actual earnings per share minus average forecasted earnings per share, divided by the share price at the beginning of the year. Finally, we use the average standard deviation of stock return (StdReturn) as a proxy of the firm information environment.

\subsection{Inputs}

The first input is the score of voluntary disclosure in annual reports (Score), measured using a selfconstructed "disclosure index." We construct this disclosure index based on the related research of Meek et al. (1995), Botosan (1997), Chau and Gray (2002), Eng and Mak (2003), Lim et al. (2007) and Francis et al. (2008). The index contains 112 items belonging to four groups: strategic (30 items), financial (36 items), non-financial (35 items), and governance information (11 items). Table 1 presents the checklist of items included in the disclosure scores.

We use three additional corporate governance inputs: Managerial ownership (ManagerOwn) is the proportion of shares held by top management. Board independence (BoardIndp) is the ratio of independent to total directors on the board. Board size (BoardSize) is the total number of directors on the board.

\section{RESULTS AND DISCUSSION}

\subsection{Descriptive Statistics}

Table 1. The Checklist Of Voluntary Disclosure This table presents the checklist of items used to develop the disclosure index. It also shows which items overlap those in existing studies.

\begin{tabular}{|l|c|}
\hline \multicolumn{1}{|c|}{ Checklist Of Items } & References \\
\hline A - Strategic information & A, B, C, E \\
\hline A1. General information about the firm & B, D \\
\hline 1. Brief history of company & B \\
2. General description of the business & B, D \\
3. Main products & A, B, C, D, E \\
4. Main Markets & A, C, E \\
\hline A2. Corporate Strategy & A, B, C, F \\
\hline 5. Statement of the main objectives & B \\
6. Statement of the financial objectives & A, B, C \\
7. Current Strategy & A, C, E \\
8. Impact of strategy on current results & A, C \\
9. Future strategy & A, C \\
10. Impact of strategy on future results & A, C, D \\
\hline A3. R \& D activities & A, C, E \\
\hline 11. Description of R \& D projects & 12. Corporate policy on R \& D \\
13. Location of R \& D activities & 14. Number employed in R \& D \\
\hline
\end{tabular}

\footnotetext{
${ }^{3}$ See Barros et al. (2013) for more details on the construction of the voluntary disclosure index.
} 


\begin{tabular}{|c|c|}
\hline \begin{tabular}{|c|} 
Checklist Of Items \\
\end{tabular} & References \\
\hline \multicolumn{2}{|l|}{ A4. Analysis and discussion of management Review of projects } \\
\hline 15. Review of operations & $\mathrm{B}$ \\
\hline 16. Competitive environment & $\mathrm{B}, \mathrm{D}$ \\
\hline 17. The most significant events & $\mathrm{B}, \mathrm{D}$ \\
\hline 18. Change in sales and profits & $\mathrm{B}, \mathrm{D}$ \\
\hline 19. Change in cost of goods sold & $\mathrm{B}, \mathrm{D}$ \\
\hline 20. Change in expenses & $\mathrm{B}, \mathrm{D}$ \\
\hline 21. Change in inventory & $\mathrm{B}, \mathrm{D}$ \\
\hline 22. Change in the share price & $\mathrm{B}, \mathrm{D}$ \\
\hline \multicolumn{2}{|l|}{ A5. Future prospects } \\
\hline 23. Future development channels & $\mathrm{A}, \mathrm{B}, \mathrm{C}$ \\
\hline 24. Qualitative forecast of sales & $\mathrm{A}, \mathrm{B}, \mathrm{C}, \mathrm{E}$ \\
\hline 25. Quantitative forecast of sales & $\mathrm{A}, \mathrm{B}, \mathrm{C}, \mathrm{D}, \mathrm{F}$ \\
\hline 26. Qualitative forecast of profits & $\mathrm{A}, \mathrm{B}, \mathrm{C}, \mathrm{D}, \mathrm{E}, \mathrm{F}$ \\
\hline 27. Quantitative forecast of profits & $\mathrm{A}, \mathrm{B}, \mathrm{C}, \mathrm{E}$ \\
\hline 28. Assumptions underlying the forecast & $\mathrm{A}, \mathrm{B}, \mathrm{C}$ \\
\hline 29. Review of forecasts & $\mathrm{A}, \mathrm{B}, \mathrm{C}$ \\
\hline 30. Description of capital project committed & $\mathrm{A}, \mathrm{B}, \mathrm{C}$ \\
\hline \multicolumn{2}{|l|}{ B - No-financial information } \\
\hline \multicolumn{2}{|l|}{ B1. Employees information } \\
\hline 1. Geographical distribution of employees & $\mathrm{A}, \mathrm{C}$ \\
\hline 2. Number of employees by sex & $\mathrm{A}, \mathrm{C}$ \\
\hline 3. Number of employees by age & $\mathrm{A}, \mathrm{C}$ \\
\hline 4. Categories of employees by function & $\mathrm{A}, \mathrm{C}$ \\
\hline 5. Number of employees for 2 or more years & $\mathrm{A}, \mathrm{C}, \mathrm{E}$ \\
\hline 6. Average compensation per employee & A, B \\
\hline 7. Added value per employee & $\mathrm{A}, \mathrm{B}$ \\
\hline 8. Data productivity & $\mathrm{A}, \mathrm{B}, \mathrm{C}$ \\
\hline 9. Safety policy & $\mathrm{A}, \mathrm{B}, \mathrm{C}$ \\
\hline 10. Cost of safety measures & $\mathrm{A}, \mathrm{C}$ \\
\hline 11. Data on accidents & $\mathrm{A}, \mathrm{C}, \mathrm{E}$ \\
\hline 12. Policy on communication & $\mathrm{A}, \mathrm{C}$ \\
\hline 13. Redundancy information & $\mathrm{A}, \mathrm{C}$ \\
\hline 14. Reason for changes in employees' number or categories over time & $\mathrm{A}, \mathrm{C}$ \\
\hline 15. Recruitment problems and related policy & $\mathrm{A}, \mathrm{C}$ \\
\hline \multicolumn{2}{|l|}{ B2. Information about the training policy } \\
\hline 16. Amount spent in training program & $\mathrm{A}, \mathrm{C}, \mathrm{E}$ \\
\hline 17. Nature of training & $\mathrm{A}, \mathrm{C}, \mathrm{E}$ \\
\hline 18. Policy on training & $\mathrm{A}, \mathrm{C}, \mathrm{E}$ \\
\hline 19. Categories of employees trained & $\mathrm{A}, \mathrm{C}, \mathrm{E}$ \\
\hline \multicolumn{2}{|l|}{ B3. Social policy and value-added information } \\
\hline 20. Safety of products & $\mathrm{A}, \mathrm{C}$ \\
\hline 21. Program of environmental protection & $\mathrm{A}, \mathrm{C}, \mathrm{E}$ \\
\hline 22. Charitable Donations & $\mathrm{A}, \mathrm{C}, \mathrm{E}$ \\
\hline 23. Community programs & $\mathrm{A}, \mathrm{C}, \mathrm{E}$ \\
\hline 24. Value added data & $\mathrm{A}, \mathrm{C}, \mathrm{E}$ \\
\hline 25. Value added ratios & $\mathrm{A}, \mathrm{C}, \mathrm{E}$ \\
\hline 26. Qualitative value-added information & $\mathrm{A}, \mathrm{C}, \mathrm{E}$ \\
\hline \multicolumn{2}{|l|}{ B4. Segmental Information } \\
\hline 27. Geographical distribution of invested capital & $\mathrm{A}, \mathrm{C}, \mathrm{E}$ \\
\hline 28. Geographical distribution of net assets & $\mathrm{A}, \mathrm{C}$ \\
\hline 29. Geographical distribution of production & $\mathrm{A}, \mathrm{C}, \mathrm{E}$ \\
\hline 30. Expenditure in the business lines & $\mathrm{A}, \mathrm{C}$ \\
\hline 31. Revenue by business line & $\mathrm{A}, \mathrm{C}$ \\
\hline 32. Competitor analysis- quantitative & $\mathrm{A}, \mathrm{C}$ \\
\hline 33. Competitor analysis- qualitative & $\mathrm{A}, \mathrm{C}$ \\
\hline 34. Market share analysis-quantitative & $\mathrm{A}, \mathrm{C}$ \\
\hline 35. Market share analysis-qualitative & $\mathrm{A}, \mathrm{C}$ \\
\hline
\end{tabular}




\begin{tabular}{|c|c|}
\hline Checklist Of Items & References \\
\hline \multicolumn{2}{|l|}{ C-Financial Information } \\
\hline \multicolumn{2}{|l|}{ C1. Performance indicators (without from the financial statements) } \\
\hline 1. Performance indicators & $\mathrm{A}, \mathrm{B}, \mathrm{C}$ \\
\hline 2. Financial data for the last five years & $\mathrm{A}, \mathrm{B}, \mathrm{C}, \mathrm{D}, \mathrm{E}$ \\
\hline 3. Turnover & $\mathrm{A}, \mathrm{B}, \mathrm{C}, \mathrm{D}, \mathrm{F}$ \\
\hline 4. Net income & $\mathrm{A}, \mathrm{B}, \mathrm{C}, \mathrm{D}, \mathrm{F}$ \\
\hline 5. Shareholders' equity & $\mathrm{A}, \mathrm{B}, \mathrm{C}, \mathrm{D}$ \\
\hline 6. Total assets & $\mathrm{A}, \mathrm{B}, \mathrm{C}, \mathrm{D}, \mathrm{F}$ \\
\hline 7. Earnings per share & $\mathrm{A}, \mathrm{B}, \mathrm{C}$ \\
\hline 8. Dividend payout policy & $\mathrm{A}, \mathrm{B}, \mathrm{C}$ \\
\hline 9. Transfer pricing policy & $\mathrm{A}, \mathrm{B}, \mathrm{C}$ \\
\hline 10. Impact of any accounting policy changes on results & $\mathrm{A}, \mathrm{B}, \mathrm{C}$ \\
\hline 11. Advertising expenditure & $\mathrm{A}, \mathrm{B}, \mathrm{C}, \mathrm{E}$ \\
\hline 12. Effect of inflation on results & $\mathrm{A}, \mathrm{B}, \mathrm{C}$ \\
\hline 13. Effect of inflation on assets & $\mathrm{A}, \mathrm{B}, \mathrm{C}$ \\
\hline 14. Effect of fluctuating interest rates on the result & $\mathrm{A}, \mathrm{B}, \mathrm{C}, \mathrm{E}$ \\
\hline \multicolumn{2}{|l|}{ C2. Financial ratios } \\
\hline 15. Liquidity Ratio & $\mathrm{A}, \mathrm{B}, \mathrm{C}, \mathrm{E}$ \\
\hline 16. Turnover ratio of assets & $\mathrm{A}, \mathrm{B}, \mathrm{C}$ \\
\hline 17. Debt ratio & $\mathrm{A}, \mathrm{B}, \mathrm{C}, \mathrm{E}$ \\
\hline 18. Profitability ratios & $\mathrm{A}, \mathrm{B}, \mathrm{C}, \mathrm{E}, \mathrm{F}$ \\
\hline 19. Other useful ratios & $\mathrm{A}, \mathrm{B}, \mathrm{C}, \mathrm{E}$ \\
\hline \multicolumn{2}{|l|}{ C3. Forecasted information } \\
\hline 20. Cash flow forecast & $\mathrm{A}, \mathrm{B}, \mathrm{C}, \mathrm{D}$ \\
\hline 21. Estimates of capital increase & $\mathrm{A}, \mathrm{B}, \mathrm{C}$ \\
\hline 22. Earnings estimates & $\mathrm{A}, \mathrm{B}, \mathrm{C}$ \\
\hline 23. Effect of inflation currency fluctuations on future operation & $\mathrm{A}, \mathrm{C}$ \\
\hline 24. Effect of currency fluctuation of interest rates on future operations & $\mathrm{A}, \mathrm{C}$ \\
\hline \multicolumn{2}{|l|}{ C4. Information on exchange rates } \\
\hline 25. Impact of currency fluctuations on current results & $\mathrm{A}, \mathrm{B}, \mathrm{C}$ \\
\hline 26. Impact of currency fluctuations on future operations & $\mathrm{A}, \mathrm{C}, \mathrm{E}$ \\
\hline 27. Estimates of currency fluctuations & $\mathrm{A}, \mathrm{B}, \mathrm{C}$ \\
\hline 28. Exchange rates used in accounting & $\mathrm{A}, \mathrm{B}, \mathrm{C}$ \\
\hline 29. Long-term debt by currency & $\mathrm{A}, \mathrm{C}$ \\
\hline 30. Short-term debt by currency & $\mathrm{A}, \mathrm{C}$ \\
\hline \multicolumn{2}{|l|}{ C5. Other financial information } \\
\hline 31. Share price at year end & $\mathrm{A}, \mathrm{C}$ \\
\hline 32. Share prices trend & $\mathrm{A}, \mathrm{C}, \mathrm{E}$ \\
\hline 33. Market capitalization at year end & $\mathrm{A}, \mathrm{C}, \mathrm{E}$ \\
\hline 34. Trend of market capitalization & $\mathrm{A}, \mathrm{C}$ \\
\hline 35. Size of shareholdings & A, C \\
\hline 36. Forecasted market share & $\mathrm{A}, \mathrm{C}, \mathrm{D}, \mathrm{F}$ \\
\hline \multicolumn{2}{|l|}{ D- Governance information } \\
\hline 1. Ownership structure & $\mathrm{A}, \mathrm{C}$ \\
\hline 2. Organizational Chart & $\mathrm{A}, \mathrm{B}, \mathrm{C}, \mathrm{E}$ \\
\hline \multicolumn{2}{|l|}{ D1. Composition of the board of director } \\
\hline 3. Personal Profile & $\mathrm{A}, \mathrm{C}$ \\
\hline 4. Description of the position occupied & $\mathrm{A}, \mathrm{C}$ \\
\hline 5. Duration of belonging to the company & $\mathrm{A}, \mathrm{B}, \mathrm{C}$ \\
\hline 6. Number of shareholders belonging to the board of directors & $\mathrm{A}, \mathrm{B}, \mathrm{C}$ \\
\hline 7. Academic profile of the directors & $\mathrm{A}, \mathrm{B}, \mathrm{C}$ \\
\hline 8. Presence of Internal Audit Committee & $\mathrm{A}, \mathrm{B}, \mathrm{C}$ \\
\hline 9. Age of the executives & $\mathrm{A}, \mathrm{B}, \mathrm{C}$ \\
\hline 10. Profile of the executives & $\mathrm{A}, \mathrm{B}, \mathrm{C}$ \\
\hline 11. Individual remuneration & $\mathrm{A}, \mathrm{B}, \mathrm{C}$ \\
\hline
\end{tabular}

A: Meek, Robert, and Gray (1995); B: Eng and Mak (2003); C: Chau and Gray (2002); D: Botosan (1997); E: Lim, Matolcsy, and Chow (2007); F: Francis, Nanda, and Olsson (2008) 
Table 2 provides descriptive statistics for all variables used in the analysis. Panel A shows the statistics of the output variables. StdReturn ranges from 13.24 to 54.18 with a mean (median) value of 26.11 (24.56), which indicates high volatility of the stock returns of SBF120 firms. Spread ranges from 0.0102 to 0.5907 , with an average (median) of $0.0728(0.0422)$. This differs from what is observed in the Anglo-Saxon stock markets. Heflin et al. (2005), for instance, finds an effective spread ranging from 0.090 to 0.436 , with an average value of 0.162 , on the US stock market. The effective spread has a standard deviation of 0.0944 , which indicates a larger dispersion than the effective spread in the US stock market, where the standard deviation of the effective spread is 0.038 (Heflin et al. 2005). Analyst forecast error (AnaError) ranges from 0 to 1.3433 with a mean (median) value of 0.3951 (0.3676). Analyst forecast error has a standard deviation of 0.3760 , which is greater than in the US (0.0694) as documented by Zhang (2006). The forecasts of financial analysts are less accurate during the crisis year of 2007 than in prior years. For instance, Boubaker and Labégorre (2006) show that analyst forecasts errors for French listed firms range from 0 to 1.556, with a mean (median) value of 0.094 (0.014) in the 1999-2000 period. Overall, the descriptive statistics of these three outputs indicate evidence of a substantial variation in information asymmetry among SBF120 firms.

Panel B presents the descriptive statistics of the input variables. Voluntary disclosure in annual reports dramatically varies among sample firms. Score has a mean (median) of 48.28 (48.50) and ranges from 26 to 73 with a standard deviation of 11.50. One-quarter of sample firms disclose less than 38 among 112 items, despite publication of several codes of best corporate governance practices in the past two decades that encourage information disclosure. This conforms with the conclusions drawn by Fitch Ratings that French firms would benefit from better financial disclosure and accountability policies. Board size also exhibits wide dispersion across the sampled firms. On average, French boards are composed of 11 directors. Board size ranges from 4 to 21 directors. Board independence varies dramatically across sample firms. Independent directors represent, on average, half the directors of French boards. However, some boards are fully independent, whereas others are composed exclusively of insiders. Managerial ownership shows systematic differences across sample firms. It ranges from a minimum of $0 \%$ to a maximum of $99 \%$, with a mean (median) value of $13.39 \%$ (3). These results are consistent with the findings of Barros et al. (2013) and Botti et al. (2014), who show that French listed firms do not exhibit similar corporate governance practices.

Table 2. Descriptive Statistics

This table summarizes the descriptive statistics of variables used in the analysis.

\begin{tabular}{|c|c|c|c|c|c|c|c|c|}
\hline & Minimum & First Quartile & Mean & Median & Third Quartile & Maximum & Standard Deviation \\
\hline \multicolumn{8}{|c|}{ Panel A: Outputs } \\
\hline StdReturn & 13.24 & 19.485 & 26.1194 & 24.56 & 30.07 & 54.18 & 8.5835 \\
Spread & 0.0102 & 0.0284 & 0.0728 & 0.0422 & 0.0790 & 0.5907 & 0.0944 \\
AnaError & 0 & 0.0319 & 0.3951 & 0.3676 & 0.6322 & 1.3433 & 0.3760 \\
\hline \multicolumn{7}{|c|}{ Panel B: Inputs } \\
\hline Score & 26 & 38.5 & 48.2857 & 48.5 & 55.5 & 73 & 11.5019 \\
BoardSize & 0 & 33.3333 & 49.3085 & 45.8041 & 63.3522 & 100 & 21.9374 \\
BoardIndp & 4 & 9 & 11.5571 & 11.5 & 14 & 21 & 3.8321 \\
Ownership & 0 & 0.1829 & 13.3993 & 3 & 15.5 & 99 & 21.6722 \\
\hline
\end{tabular}

\subsection{B-Convex Application Results}

The present paper sheds some light on the role of corporate governance and voluntary disclosure on the firm information environment. Our model is output-oriented because we consider that the quality of the firm information environment depends mainly on corporate governance mechanisms (i.e., board of directors and ownership structure) and voluntary disclosure decisions. Table 3 provides efficiency scores for sample firms. Firms are defined as Decision Managerial Unities (DMUs). The efficiency scores are the solution of the optimization program presented in Section 2. 
Table 3.

This table presents the efficiency scores of our sampled firms (DMUs)

\begin{tabular}{|c|c|c|c|c|c|c|c|}
\hline \multicolumn{8}{|c|}{ Panel A: B-Convex Application Results } \\
\hline DMU & $\begin{array}{c}\text { Efficiency } \\
\text { Scores }\end{array}$ & DMU & $\begin{array}{c}\text { Efficiency } \\
\text { Scores }\end{array}$ & DMU & $\begin{array}{c}\text { Efficiency } \\
\text { Scores }\end{array}$ & DMU & $\begin{array}{c}\text { Efficiency } \\
\text { Scores }\end{array}$ \\
\hline 1 & 1.3449 & 24 & 1 & 36 & 1 & 59 & 1 \\
\hline 2 & 1 & 25 & 1 & 37 & 1 & 60 & 1.2685 \\
\hline 3 & 1.9966 & 26 & 1 & 38 & 1 & 61 & 1.0792 \\
\hline 4 & 1 & 27 & 1 & 39 & 1 & 62 & 1 \\
\hline 5 & 1 & 28 & 1 & 40 & 1.3883 & 63 & 1 \\
\hline 6 & 1 & 29 & 1 & 41 & 1.2581 & 64 & 1 \\
\hline 7 & 2.4927 & 30 & 1 & 42 & 1.6406 & 65 & 1 \\
\hline 8 & 1 & 31 & 1 & 43 & 1 & 66 & 1 \\
\hline 9 & 1.1915 & 32 & 1 & 44 & 1 & 67 & 1 \\
\hline 10 & 1 & 33 & 1 & 45 & 1.0669 & 68 & 1 \\
\hline 11 & 1 & 34 & 1 & 46 & 1 & 69 & 1.4821 \\
\hline 12 & 1 & 35 & 1 & 47 & 1.4964 & 70 & 1 \\
\hline 13 & 1.8105 & 25 & 1 & 48 & 1 & 62 & 1 \\
\hline 14 & 1.1122 & 26 & 1 & 49 & 1 & 63 & 1 \\
\hline 15 & 1 & 27 & 1 & 50 & 1 & 64 & 1 \\
\hline 16 & 1.0169 & 28 & 1 & 51 & 1.5535 & 65 & 1 \\
\hline 17 & 1.0729 & 29 & 1 & 52 & 1 & 66 & 1 \\
\hline 18 & 1 & 30 & 1 & 53 & 1 & 67 & 1 \\
\hline 19 & 1.2310 & 31 & 1 & 54 & 1 & 68 & 1 \\
\hline 20 & 1.4547 & 32 & 1 & 55 & 1 & 69 & 1.4821 \\
\hline 21 & 1 & 33 & 1 & 56 & 1.2698 & 70 & 1 \\
\hline 22 & 1 & 34 & 1 & 57 & 1 & & \\
\hline 23 & 1.3870 & 35 & 1 & 58 & 1.0139 & & \\
\hline \multirow{2}{*}{\multicolumn{4}{|c|}{ Total number of efficient firms }} & \multicolumn{4}{|c|}{48} \\
\hline \multicolumn{2}{|c|}{ Percentage of efficient firms } & & & \multicolumn{4}{|c|}{68.5714} \\
\hline
\end{tabular}

Panel B: Descriptive statistics of efficiency scores

This table summarizes the characteristics (descriptive statistics) of efficiency scores obtained from B-convex model Descriptive statistics of efficiency scores

Minimum
First quartile
Mean
Median
Third quartile
Maximum
Standard deviation

1
1
1.1232
1
1.0777
2.4927
0.2683

Efficiency scores equal 1 for 48 DMUs, corresponding to $68.57 \%$ of sample firms, which means that these DMUs are located on the efficiency frontier. Ownership structure, board monitoring, and voluntary disclosure in these firms seem to be effective in improving the firm information environment. Under good corporate governance practices, among other factors, better board characteristics and voluntary disclosure appear to reduce uncertainty, improve the quality of analyst forecasts, and mitigate the adverse selection problem.

The results also show that 31.42\% (22 DMUs, including DMUs 1, 2, 9, 13, and 23) have efficiency scores equal to or greater than 1 . This result suggests that these 22 DMUs can improve their information environment using the same characteristics of their boards of directors and the same level of voluntary disclosure. For instance, with the 
same governance practices, DMUs 1, 9, and 23 can reduce their information asymmetry levels, respectively, by $34.49 \%, 19.15 \%$, and $38.70 \%$, thereby improving, subsequently, their information environment. Governing characteristics, including among other factors, board composition, board size, ownership structure, and voluntary disclosures do not appear effectively to reduce information asymmetry and improve the firm information environment. Moreover, the percentage of inefficient firms is considered large for SBF 120 firms that exhibit the highest market capitalizations, suggesting the presence of inefficiency problems due to ownership structure, board composition, and firm disclosure policy.

Consistent with prior studies (e.g., Ben Ali, 2013), we show that in France, a market characterized by poor investor protection, firms that exhibit poor internal corporate governance mechanisms present low disclosure, leading to higher information asymmetry and poor firm information environment. A significant proportion of SBF120 firms need to improve their governance practices and disclosure policy to be more effective in improving their information environment.

\section{CONCLUSION}

This study sheds further light on the role of corporate governance and voluntary disclosure in shaping the firm information environment. Our empirical analysis uses non-parametric B-convexity methodology on a sample of 70 French listed firms belonging to the SBF120 index. The findings of the B-convexity approach show that $68.57 \%$ of sample firms are efficient (48 firms). Corporate governance mechanisms, such as boards of directors and disclosure policy, appear to effectively monitor the top executives of these firms, which reduces information asymmetry between insiders and outsiders. Such firms disclose more voluntary information needed by various stakeholders to assess firm performance and to make sound decisions, which in turn improves their information environment. The remaining 22 firms have efficiency scores different than 1, suggesting that they lie below the efficiency frontier. Ownership structure, board characteristics, and voluntary disclosure of these firms appears to lead to higher information asymmetry, lower analyst forecast accuracy, and higher stock return volatility, resulting in a more opaque information environment. These findings suggest that there is room to improve the quality of the information environment of SBF120 firms.

The findings of this study hold interesting theoretical and practical implications. First, this study sets forth an original way to gauge the role and effectiveness of corporate governance mechanisms and disclosure decisions in improving the firm information environment. Second, it uses a new approach based on B-convexity methodology to compute the efficiency scores. Third, it helps French policy makers and regulators, since it points out the weaknesses in corporate governance practices that lead to a low-quality information environment.

The results of this study should be interpreted cautiously, given the presence of several limitations common to all similar studies. First, B-convexity results depend on the choice of input variables, as in other data envelopment techniques. We draw from the literature to select a battery of relevant inputs that alone influence the outputs to reduce the effects of this limitation (Thanassoulis, 2001). The chosen inputs are the most relevant determinants of the firm information environment, which limits the sensitivity of the results to the inputs. Second, as in prior studies, one may question the homogeneity of the firms that comprise our sample, in spite of multiple characteristics common to all sample firms (i.e., belonging to the SBF120 index, greater liquidity, large size, important foreign ownership, followed by many financial analysts, etc.). Firms that do not belong to the same industry may face different market conditions, which may make their comparability more difficult. However, one can always claim that firms are not homogeneous and not comparable to be together in the same sample for a B-convexity analysis. In addition, applying a B-convexity approach for a small sample of 70 non-financial firms increases the probability that a given firm will be found relatively efficient, thus limiting the general character of the results. Third, the research design does not permit disentangling, which among board characteristics, disclosure policy, and ownership structure operates more effectively compared to the others. 


\section{AUTHORS' INFORMATION}

Sabri Boubaker is Associate Professor of Finance at Champagne School of Management (Groupe ESC Troyes en Champagne, France) and Research Fellow at the Institut de Recherche en Gestion (University of Paris Est). He holds a Ph.D. in Finance from University of Paris Est (2006) and a HDR degree (Habilitation for Supervising Doctoral Research) in 2010 from the same university. He was a visiting professor at IESEG School of Management (France) and IAE Paris Gustave Eiffel (France). He has recently published several academic papers in international refereed journals including Journal of Banking and Finance, International Review of Financial Analysis, Economic Modeling, Review of Accounting and Finance, Multinational Finance Journal, Global Finance Journal, International Journal of Business, North American Journal of Economics and Finance, and Journal of International Financial Markets, Institutions and Money. Dr. Boubaker has also edited several special issues in peer-reviewed journals, several books on corporate governance and corporate social responsibility issues. He is the co-founder of the Paris Financial Management Conference (PFMC, Paris, France).

Email: sabri.boubaker@get-mail.fr

Amal Hamrouni is an Assistant Professor of Accounting and Finance at La Rochelle Business School and Research Fellow at CAEPEM (Centre d'Analyse de l'Efficience et de la Performance en Economie et Management, University of Perpignan via Domitia). She holds a Ph.D. in Finance from University of Perpignan (2013). She has participated in many international conferences and has published several academic papers in international referred journals including the Journal of Applied Business Research and Review of Accounting and Finance.

Email: hamrounia@esc-larochelle.fr

Qi-bin Liang holds a PhD in Economic Science from University of Perpignan via Domitia (France). He was a postdoctoral researcher at CAEPEM before joining University of Perpignan as lecturer. His main research interest includes financial mathematics. His work has been published in leading journals such as the Journal of Economics, European Journal of Operational Research and Economic Modeling.

Email: qi-bin.liang@univ-perp.fr

\section{REFERENCES}

1. Akerlof, G. (1970). The Market for Lemons: Quality Uncertainty and the Market Mechanism. Quarterly Journal of Economics, 84 (3) 488-500.

2. Anderson, R., Mansi, S. \& David, R. (2004). Board characteristics, accounting report integrity, and cost of debt. Journal of Accounting and Economies, 37 (3) 315-342.

3. Attig, N. (2007). Family pyramidal holdings and board of directors. International Journal of Business Governance and Ethics, 3 (4) 394-406.

4. Attig, N., Fong, W.M., Gadhoum, Y. \& Lang, L.H.P. (2006). Effects of Large Shareholding on Information Asymmetry and Stock Liquidity. Journal of Banking and Finance, 30 (10) 2875-2892.

5. Ascioglu, A., Hegde, P., Krishnan, G. \& McDermott, J. (2012). Earnings Management and Market Liquidity. Review of Quantitative Finance and Accounting, 38 (2) 257-274.

6. Baik, B., Kang, J.K. \& Morton, R. (2010). Why are Analysts Less Likely to Follow Firms with High Managerial Ownership?. Journal of Accounting Auditing and Finance, 25(2) 171-200.

7. Barros, C.P., Boubaker, S. \& Hamrouni, A. (2013). Corporate Governance and Voluntary Disclosure in France. Journal of Applied Business Research, 29 (2) 1-17.

8. Ben Ali, C. (2013). Qualité de la publication financière et mécanismes de gouvernance en France. Management et Avenir, 3 (61) 109-128.

9. Bhattacharya, N., Ecker, F., Olsson, P. M. \& Schipper, K. (2012). Direct and Mediated Associations among Earnings Quality, Information Asymmetry, and the Cost of Equity. The Accounting Review, 87 (2) 449482.

10. Botosan, C.A. (1997). Disclosure Level and the Cost of Equity Capital. Accounting Review, 72 (3) $323-$ 349.

11. Botti, L., Boubaker, S., Hamrouni, A. \& Solonandrasana, B. (2014). Corporate governance efficiency and Internet financial reporting quality. Review of Accounting and Finance, 13 (1) 43-64. 
12. Briec, W. \& Liang, Q.B. (2011). On Some Semilattice Structures for Production Technologies. European Journal of Operational Research, 215 (2) 740-749.

13. Brown, S. \& Hillegeist, S.A. (2007). How Disclosure Quality affects the Level of Information Asymmetry. Review of Accounting Studies, 12 (2-3) 443-477.

14. Cai, C., Keasey, K. \& Short, H. (2006). Corporate Governance and Information Efficiency in Security Markets. European Financial Management, 12 (5) 763-787.

15. Chau, G.K. \& Gray, S.J. (2002). Ownership Structure and Corporate Voluntary Disclosure in Hong Kong and Singapore. The International Journal of Accounting, 37 (2) 247-265.

16. Chen, C.J. \& Jaggi, B. (2000). Association between Independent Non-Executive Directors, Family Control and Financial Disclosure in Hong Kong. Journal of Accounting and Public Policy, 19 (4/5) 285-310.

17. Chen, W.P., Chung, H., Lee, C. \& Lia, W.L. (2007). Corporate Governance and Equity Liquidity: analysis of S\&P transparency and disclosure rankings. Corporate Governance: An International Review, 15, (4) 644-660.

18. Cheng, E.C.M. \& Courtenay, S.M. (2006). Board Composition, Regulatory Regime and Voluntary Disclosure. The International Journal of Accounting, 41 (3) 54-81.

19. Cheng, Q. \& Warfield, T.D. (2005). Equity Incentives and Earnings Management. The Accounting Review, 80 (2) 441-476.

20. Chung, Kee H., Elder, J. \& Kim, J.C. (2010). Corporate Governance and Liquidity. Journal of Financial and Quantitative Analysis, 45 (2) 265-291.

21. Cooke, T.E. (1992). The Impact of Size, Stock Market Listing and Industry Type on Disclosure in the Annual Reports of Japanese Listed Corporations. Accounting and Business Research, 22 (87) 229-237.

22. Dahya, J., Dimitrov, O. \& McConnell, J. (2008). Dominant shareholders, corporate boards, and corporate value: A cross-country analysis. Journal of Financial Economics, 87 (1) 73-100.

23. Diamond, D. (1985). Optimal Release of Information by Firms. Journal of Finance, 40 (4) $1071-1094$.

24. Diamond, D. \& Verrecchia, R. (1991). Disclosure, Liquidity, and the Cost of Capital. Journal of Finance, 46 (4) 1325-1359.

25. Eng, L.L. \& Mak, Y.T. (2003). Corporate Governance and Financial Disclosure. Journal of Accounting and Public Policy, 22 (4) 325-345.

26. Grossman, S. (1981). The Informational Role of Warranties and Private Disclosure About Product Quality. Journal of Law and Economics, 24 (3) 461-483.

27. Fama, E. \& Jensen, M. (1983). Separation of Ownership and Control. Journal of Law and Economics, 26 (2) 301-326

28. Francis, J., Nanda, D. \& Olsson. P. (2008). Voluntary Disclosure, Earnings Quality and Cost of Capital. The Journal of Accounting Research, 46 (1) 53-99.

29. Jensen, M.C. (1993). The Modern Industrial Revolution, Exit, and the Failure of Internal Control Systems. The Journal of Finance, 48 (3) 831-880.

30. Jensen, M.C. \& Meckling, W.H. (1976). Theory of the Firm: Managerial Behavior, Agency Costs and Ownership Structure. Journal of Financial Economics, 3 (4) 305-360.

31. Heflin, F., Shaw, W. \& Wild, J. (2005). Disclosure Policy and Market Liquidity: Impact of Depth Quotes and Order sizes. Contemporary Accounting Research, 22 (4) 829-866.

32. Kanagaretnam, K., Lobo, G.J. \& Whalen, D.J. (2007). Does good corporate governance reduce information asymmetry around quarterly earnings announcements?. Journal of Accounting and Public Policy, 26 (4) 497-522.

33. Lang, M. \& Lundholm, R. (1996). Corporate Disclosure Policy and Analyst Behaviour. The Accounting Review, 71 (4) 467-492.

34. Lang, M. \& Lundholm, R. (1993). Cross-sectional Determinants of Analyst Ratings of Corporate Disclosures. Journal of Accounting Research, 31 (2) 246-271.

35. Lim, S., Matolcsy, Z. \& Chow, D. (2007).The Association between Board Composition and Different Types of Voluntary Disclosure. European Accounting Review, 16 (3) 555-583.

36. Meek, G.K., Robert G.B. \& Gray, S.J. (1995). Factor Influencing Voluntary Annual Report Disclosure by US, UK and Continental Europe Multinational Corporations. Journal of International Business Studies, 26 (3) $555-572$.

37. Neu, D., Warsame, H. \& Pedwell, K. (1998). Managing Public Impressions: Environmental Disclosures in Annual Reports. Accounting, Organisations and Society, 23 (3) 265-282. 
38. O’Hara, M. (1995). Market Microstructure Theory. Blackwell Publishers

39. Patelli, L., Prencipe, A. (2007). The Relationship between Voluntary Disclosure and Independent Directors in the Presence of Dominant Shareholders. European Accounting Review, 16 (1) 5-33.

40. Spence, M. (1973). Job Marketing Signalling. The Quarterly Journal of Economics 87 (3) $355-374$.

41. Thanassoulis, E. (2001). Introduction to the theory and application of data envelopment analysis: A foundation text with integrated software. Kluwer Academic Publishers Norwell, MA, USA.

42. Zarb, B. J. (2007). Voluntary Disclosures of Forward-looking Earnings Information and Firm Value in the Airline Industry. International Journal of Business Research, 7 (6) 1-19.

43. Zhang, F.X. (2006). Information Uncertainty and Analyst Forecast Bahavior. Contemporary Accounting Research, 23 (2) 565-590. 
NOTES 